ACTA MYCOLOGICA

Vol. 44 (2): 259-264

2009
Dedicated to Professor Krystyna Czyżewska

in honour of 40 years of her scientific activity

\title{
Japewia tornoensis and further localities of $J$. subaurifera found in the Carpathians
}

\author{
PAWEŁ CZARNOTA
}

Department of Agroecology, University of Rzeszów, Ćwiklińskiej 2, PL-35-601 Rzeszów Scientific Laboratory of the Gorce National Park, Poręba Wielka 590, PL-34-735 Niedźwiedź pawczarnota@poczta.onet.pl

Czarnota P.: Japewia tornoensis and further localities of J. subaurifera found in the Carpathians. Acta Mycol. 44 (2): 259-264, 2009.

Japewia tornoensis is reported for the first time from the Carpathians and Poland. Further localities of J. subaurifera, known so far from a single Carpathian collection in the Polish Tatra Mts., are also presented. Some diagnostic features and general distribution of both species are provided and similar taxa are discussed.

Key words: Japewia, lichenized fungi, sorediate lichens, Western Carpathians, Poland

\section{INTRODUCTION}

The lichen forming genus Japewia (Lecanorales, Ascomycota), described recently by Tønsberg (1990) includes only two species, J. subaurifera Muhr \& Tønsberg and J. tornoensis (Nyl.) Tønsberg. From Poland the first one was reported so far. Its single locality in the Polish Tatra Mountains was also known as only one in the whole Carpathians (Bielczyk et al. 2004; Czarnota, Kukwa 2004). The author supposed, however, that the species also occurs in other parts of this Central European mountains, at least in regions covered with upper montane spruce forests. Field investigations carried out in Western Carpathians in 2008-2009 confirmed that suggestion and brought several succeeding records of $J$. subaurifera. Surprisingly, during this intensive work on diversity of epixylic lichens presuming dead spruces, J. tornoensis has also been discovered in the Gorce Mts. being a new lichen species for the Carpathians and Poland. 


\section{MATERIAL AND METHODS}

The material was examined with light microscopes. Hand-made apothecial sections and squashed thallus preparations, were studied in water and potassium hydroxide solution (K). Collections of J. subaurifera were compared with other Polish materials checked previously by B. J. Coppins (UK). The material is stored in the Herbarium of the Gorce National Park (GPN). The nomenclature follows Index Fungorum (http://indexfungorum.org; date of exploration: July 2009) and Liška et al. (2008).

\section{THE SPECIES}

Japewia subaurifera Muhr \& Tønsberg, Lichenologist 22 (3): 206 (1990).

Morphology and affinities. Descriptions and illustrations of the species are given for example by Tønsberg (1990) and Ohmura \& Kashiwadani (1997). All collections presented here correspond well with those descriptions and Tatra's specimens determined previously by Coppins (Czarnota, Kukwa 2004). They are only sterile as most European findings forming brown-yellow, orange-brown to yellowish green soralia (Fig. 1). Because of similarly coloured soralia J. subaurifera resembles Lecidea pullata (Norman) Th. Fr. and Caloplaca lucifuga Thor. It is especially similar to the first species which covers often the same substrates being common in upper montane belt in Carpathians. The second one grows mainly on deciduous trees, particularly often in crevices of rough bark of old Quercus spp., rather in lowland woodlands than in mountains. Each of them differ in the chemistry since J. subaurifera produces lobaric acid and several 'subaurifera' pigments, L. pullata spaerophorin and isosphaeric acid, while C. lucifuga has parietin and fallacinal (Tønsberg 1992; Wirth 1995). From those reasons the orange-brown soralia of the last species react $\mathrm{K}+$ red-violet in contrast to $\mathrm{K}+$ fuscous brown soralia of $J$. subaurifera (visible in a squash preparation). Soralia of $L$. pullata give no reaction with $\mathrm{K}$ or they are only $\mathrm{K} \pm$ yellowish.

Ecology. The species grows on bark of several deciduous trees, mainly Betula spp., Alnus incana and Sorbus aucuparia (Tønsberg 1992) but except Scandinavia it is found more often on different conifer trees in large woodlands from about see-level in north-west Norway to upper montane belt in mountains of Central Europe and Japan. In Poland it was collected only in upper montane spruce forest PlagiothecioPiceetum growing as an epiphyte on Picea abies and Pinus cembra or as an epixyle of hard wood on decorticated spruce trunks. It prefers old, natural stands showing some implication to be an indicator of ecological continuity of these forest ecosystems. Its ecological role was taken into account also in Scottish native pinewoods, where J. subaurifera is considered as the 'Bonus' species (Coppins, Coppins 2002). Accompanied taxa for the new Polish findings include: Calicium trabinellum (Ach.) Ach., Chaenotheca spp., Elixia flexella (Ach.) Lumbsch, Fuscidea pusilla Tønsberg, Hypogymnia physodes (L.) Nyl., Hypocenomyce caradocensis (Leight. ex Nyl.) P. James \& Gotth. Schneid., H. scalaris (Ach.) M. Choisy, Lecanora conizaeoides Nyl. ex Cromb., L. phaeostigma (Körb.) Almb., L. pulicaris (Pers.) Ach., L. subintricata 
(Nyl.) Th. Fr., Lecidea leprarioides Tønsberg, L. nylanderi (Anzi.) Th. Fr., L. turgidula Fr. and Mycoblastus sanguinarius (L.) Norman.

World distribution. $J$. subaurifera is a widespread lichenized fungus reported mainly from the zone of boreal forests in the Northern Hemisphere. It is especially frequent in Scandinavia; particularly in Norway and Sweden (Tønsberg 1990). From other European sites, including Scotland, Iceland, Komi Republic in Russia, Estonia and mountainous areas of Portugal, the Czech Republic (Šumava, České Švýcarsko, Eastern Sudetes), Austria and Turkey it is known from sparse localities (Boom van den, Giralt 1996; Kristinsson 1999; Palice 1999; Halonen et al. 2000; Tønsberg et al. 2001; Czarnota, Kukwa 2004; Halda 2006). J. subaurifera seems to be also widespread throughout boreal zone of North America (Tønsberg 1990, 1992; McCune et al. 2000; Hauck et al. 2006); its locally frequent occurrence on Japan island Hokkaido is also known (Ohmura, Kashiwadani 1997). Up to date the single locality from Polish Tatra Mts. was considered as only one in whole Carpathians (Czarnota, Kukwa 2004). The new findings presented here extend its occurrence on other ranges of Western Carpathians.

SPecimens EXAmined (all within upper montane spruce forest Plagiothecio-Piceetum). Poland. ATPOL grid square Gd 27 - Western Beskidy Mts., Babia Góra Massif, Babia Góra National Park, NE slope of Sokolica Mt., 49 $35^{\prime} 10.4^{\prime \prime} \mathrm{N}, 19^{\circ} 34^{\prime} 06.5^{\prime \prime}$ E, alt. $1250 \mathrm{~m}$, on wood of decorticated trunk of Picea

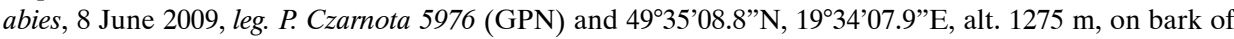
Picea abies, 8 June 2009, leg. P. Czarnota 5981 (GPN). Ge 11 - Western Beskidy Mts., Gorce Mts., Gorce National Park, forest section no. 8c, N slope of Kudłoń Mt., $49^{\circ} 34.448^{\prime} \mathrm{N}, 20^{\circ} 10.583^{\prime} \mathrm{E}$, alt. $1210 \mathrm{~m}$, on wood of Picea abies, 18 May 2009, leg. P. Czarnota 5986 (GPN). Ge 21 - Gorce Mts., Gorce National Park, forest section no. $184 \mathrm{~b}, \mathrm{~W}$ of Gabrowska glade, $49^{\circ} 32.595^{`} \mathrm{~N}, 20^{\circ} 08.510^{\prime} \mathrm{E}$, alt. $1245 \mathrm{~m}$, on bark of Picea abies, 29 Aug. 2008, leg. P. Czarnota 5632 (GPN).

Japewia tornoensis (Nyl.) Tønsberg - Lichenologist 22 (3): 206 (1990).

Syn. Lecidea tornoënsis Nyl., Herb. Mus. Fenn.: 110 (1859); Biatora tornoënsis (Nyl.) Th. Fr., Nova Acta R. Soc. Scient. upsal. 3: 296 (1861); Mycoblastus tornoënsis (Nyl.) R. A. Anderson, Bryologist 77 (2): 220 (1974).

Morphology and affinities. Considering similar lichens growing in the upper montane belts of Western Carpathians, J. tornoensis at first sight resembles paler (shaded) forms of Strangospora moriformis (Ach.) Stein by semiglobose, immarginate, brown to dull brown apothecia (Fig. 2). Mature apothecia of Lecanora phaeostigma with reduced excipulum are also very similar to those formed by J. tornoensis (Fig. 3). Growing closely to the both species, J. tornoensis could easily be overlooked thus its real distribution in the Carpathians seems to be wider than we currently known. Its distinguishing from the letter species is quite simple by anatomic characters, mainly by distinct differences in ascus shape and strongly thickened spores (walls $1.5-3 \mu \mathrm{m})$, which are large $(15-20 \times 10-15 \mu \mathrm{m})$ and additionally coated by thick gelatinous epispore (Figs 4, 5). L. phaeostigma has much smaller, ellipsoid and thin-walled spores and moreover very often visible numerous brown black pycnidia. $S$. moriformis forms globose, small ascospores and multispored asci. For more details see for example Tønsberg (1990) and Hawksworth \& Coppins (1992).

Ecology. Except Antarctica and oceanic parts of Europe, where J. tornoensis has been found on terricolous bryophytes and humus in rock crevices (Hawksworth, Coppins 1992; Olech 2004), almost all its inland reports are made in subalpine belts covered with conifer forest. It was collected there mainly as an epiphyte on, e.g., 
Larix decidua, Pseudotsuga manziesii, Picea engelmannii, Abies lasiocarpa and rarely on wood.

Studies of Hauck and Spribille (2005) in spruce-fir forests of northwestern Montana suggest that J. tornoensis principally occupies branches of conifer trees. Perhaps the species prefers the same kind of habitat also in the Carpathians, as would indicate the finding presented here.

World distribution. J. tornoensis is a widespread bipolar species, however except Arctic regions is rather rarely reported elsewhere. It is known from Austria (Alps; e.g. Obermayer 1997; Hafellner et al. 2003), Germany (Bayern; Scholz 2000), whole Scandinavia (Santesson 2004) including Svalbard (Elvebakk, Hertel 1997), Switzerland (Scheidegger et al. 2002), British Isles (C Scotland; Hawksworth, Coppins 1992), Iceland, Greenland, Canada, Alaska, almost all geographical regions of Arctic Russia (Thomson 1997; Kristinsson et al. 2006), Mongolia (Hauck, Javkhlan 2008), Japan (Kurokawa 2003), USA: e.g., Colorado (Anderson, Carmer 1974), Arizona (Obermayer 1997), New York (Harris 2004), Montana (Hauck, Spribille 2005) as well as Antarctica (Øvstedal, Lewis Smith 2001; Olech 2004).

Specimen examined. Poland. Ge 21 - Western Beskidy Mts, Gorce Mts., Gorce National Park, forest section no. 158a, E of Jaworzyna Kamienicka Mt., 49³2.794'N, 2009.901'E, alt. 1250 m, on hard wood of spruce branch within upper montane spruce forest Plagiothecio-Piceetum, 2 Oct. 2008, leg. P. Czarnota 5637 (GPN), det. Z. Palice.

Acknowledgements. Dr. Z. Palice (Průhonice, Czech Republic) is thanked for turn my attention towards J. tornoensis and his hospitality during my stay in Průhonice in 2009. The work is a part of project supported by Polish Ministry of Science and Higher Education, grant no. N N304 306835.

\section{REFERENCES}

Anderson R. A., Carmer M. B. 1974. Additions to the lichen flora of Colorado. Bryologist 77: 216-223.

Bielczyk U., Lackovičová A., Farkas E., Lőkös L., Liška J., Breuss O., Kondratyuk S.Y. 2004. Checklist of lichens of the Western Carpathians. W. Szafer Institute of Botany, Polish Academy of Sciences, Kraków, 181 pp.

Boom van den P. P. G., Giralt M. 1996. Contribution to the flora of Portugal, lichens and lichenicolous fungi I. Nova Hedwigia 63 (1/2): 145-172.

Coppins A. M., Coppins B. J. 2002. Indices of ecological continuity for woodland epiphytic lichen habitats in the British Isles. British Lichen Society, Wimbledon, $36 \mathrm{pp}$.

Czarnota P., Kukwa M. 2004. Some sorediate lichens and lichenicolous fungi new to Poland. Graphis Scripta 15: 24-32.

Elvebakk A., Hertel H. 1997. A catalogue of Svalbard lichens. (In:) A. Elvebakk, P. Prestrud (eds). A Catalogue of Svalbard Plants, Fungi, Algae and Cyanobacteria. Norsk Polarinstitutt Skrifter 198: 271-359.

Hafellner J., Obermayer W., Breuss O., Türk R. 2003. Flechtenfunde in den Schladminger Tauern in der Steiermark (BLAM-Exkursion 2001). Herzogia 16: 187-206.

Halda J. P. 2006. Interesting lichen records from Králický Sněžnik Mts. (Glatzer Schneeberg, Czech Republic). (In:) A. Lackovičová, A. Guttová, E. Lisická, P. Lizoň (eds). Central European lichens - diversity and threat. Mycotaxon: 315-324.

Halonen P., Kukwa M., Motiejūnaitė J., Lõhmus P., Martin L. 2000. Notes on lichens and lichenicolous fungi found during the XIV Symposium of Baltic Mycologists and Lichenologists in Järvselja, Estonia. Folia Cryptogamica Estonica 36: 17-21.

Harris R. C. 2004. A preliminary list of the lichens of New York. Opuscula Philolichenum 1: 55-74.

Hauck M., Hofmann E., Schmull M. 2006. Site factors determining epiphytic lichen distribution in a dieback-affected spruce-fir forest on Whiteface Mountain, New York: microclimat. Annales Botanici Fennici 43: 1-12. 
Hauck M., Javkhlan S. 2008. Epiphytic lichen diversity and its dependence on bark chemistry in the northern Mongolian dark taiga. Flora - Morphology, Distribution, Functional Ecology of Plants 204: 278-288.

Hauck M., Spribille T. 2005. The significance of precipitation and substrate chemistry for epiphytic lichen diversity in spruce-fir forests of the Salish Mountains, northwestern Montana. Flora 200: 547-562.

Hawksworth D. L., Coppins B. J. 1992. Lecidea Ach. (1803). (In:) O. W. Purvis, B. J. Coppins, D. L. Hawksworth, P. W. James, D. M. Moore (eds). The lichen flora of Great Britain and Ireland. Natural History Museum Publications with the British Lichen Society, London: 318-336.

Kristinsson H. 1999. The 12th meeting of the Nordic Lichen Society in Eidar, Iceland 1997. Graphis Scripta 11 (1): 13-21.

Kristinsson H., Hansen E.S., Zhurbenko M. 2006. Panarctic Lichen Checklist. Internet version. http:// archive.arcticportal.org/276/01/Panarctic_lichen_checklist.pdf

Kurokawa S. (ed.). 2003. Checklist of Japanese Lichens. National Science Museum, Tokyo, 128 pp.

Liška J., Palice Z., Slavíková Š. 2008. Checklist and Red List of lichens of the Czech Republic. Preslia 80: 151-182.

McCune B., Rosentreter R., Ponzetti J. M., Shaw D. C. 2000. Epiphyte habitats in an old conifer forest in western Washington, U.S.A. Bryologist 103: 417-427.

Obermayer W. 1997. Lichenotheca Graecensis. Fasc. 4 (Nos 61-80). Fritschiana 8: 1-6.

Ohmura Y., Kashiwadani H. 1997. Lichens of Mt. O-akan and its adjacent areas, Hokkaido, Japan. Bulletin of the National Science Museum (Tokyo), Series B (Botany) 23: 1-24.

Olech M. 2004. Lichens of King George Island, Antarctica. The Institute of Botany of the Jagiellonian University, Kraków, 391 pp.

Øvstedal D. O., Lewis Smith R. I. 2001. Lichens of Antarctica and South Georgia. Cambridge University Press, Cambridge, $411 \mathrm{pp}$.

Palice Z. 1999. New and noteworthy records of lichens in the Czech Republic. Preslia 71: 289-336.

Santesson R., Moberg R., Nordin A., Tønsberg T., Vitikainen O. 2004. Lichen-forming and lichenicolous fungi of Fennoscandia. Museum of Evolution, Uppsala University, Uppsala, Sweden, 359 pp.

Scheidegger C., Clerc P., Dietrich M., Frei M., Groner U., Keller C., Roth I., Stofer S., Vust M. 2002. Rote Liste der gefährdeten Arten der Schweiz: Baum- und erdbewohnende Flechten. Hrsg. Bundesamt für Umwelt, Wald und Landschaft BUWAL, Bern and Eidgenössische Forschungsanstalt WSL, Birmensdorf and Conservatoire et Jardin botaniques de la Ville de Genève CJBG. BUWAL-Reihe Vollzug Umwelt, 124 pp.

Scholz P. 2000. Katalog der Flechten und flechtenbewohnenden Pilze Deutschlands. Schriftenreihe für Vegetationskunde 31: 4-298.

Thomson J. W. 1997. American Arctic Lichens. II. The Microlichens. University of Wisconsin Press, Madison, $688 \mathrm{pp}$.

Tønsberg T. 1990. Japewia subaurifera, a new lichen genus and species from north-west Europe and western North America. Lichenologist 22: 205-212.

Tønsberg T. 1992. The sorediate and isidiate, corticolous, crustose lichens in Norway. Sommerfeltia 14: $1-331$.

Tønsberg T., Türk R., Hofmann P. 2001. Notes on the lichen flora of Tyrol (Austria). Nova Hedwigia 72 (3/4): 487-497.

Wirth V. 1995. Die Flechten Baden-Württembergs. Verlag E. Ulmer, Stuttgart, 1006 pp. 
Japewia tornoensis i kolejne stanowiska J. subaurifera odnalezione w Karpatach

\section{Streszczenie}

Rodzaj Japewia (grzyby zlichenizowane) obejmuje dwa gatunki, J. tornoensis i J. subaurifera. Pierwszy, o bipolarnym charakterze występowania na świecie, został stwierdzony po raz pierwszy w Karpatach (Gorce) i w Polsce. Drugi, znany przede wszystkim z borealnych obszarów Półkuli Północnej, notowany był dotychczas w Karpatach tylko na jednym stanowisku, w Tatrach (Czarnota, Kukwa 2004). Teraz odnaleziono go także w Gorcach i na Babiej Górze. Oba gatunki w całej Europie Środkowej są uznawane za rzadkie.

J. subaurifera występuje przede wszystkim w postaci płonnej, wykształcając charakterystyczne, brunatnawożółte, pomarańczowobrunatne lub zielonawożółte soralia produkujące kwas lobariowy i kilka pigmentów „subaurifera” (m. in. secalonic acid i eumitryn). W Karpatach Zachodnich gatunek ten rośnie na korze starych świerków i na twardym drewnie pni świerkowych w górnoreglowym borze świerkowym Plagiothecio-Piceetum. Lokuje się ponad podstawą pnia, zajmując tym samym odmienną niszę ekologiczną niż Lecidea pullata - inny, morfologicznie podobny, „sorediowany” i częsty w tym zbiorowisku leśnym grzyb zlichenizowany.

J. tornoensis wykształca półkoliste, brunatnoczerwone apotecja przypominające wyglądem jaśniejsze (ocienione) formy Strangospora moriformis, a także Scoliciosporum chlorococcum czy też Lecanora phaeostigma. Gatunek ten łatwo jest odróżnić po charakterystycznych, gru-

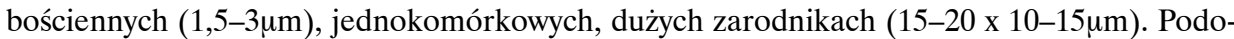
bieństwo do tych pospolitych porostów pozwala przypuszczać, że może to być gatunek częstszy w Karpatach, lecz przeoczany. 

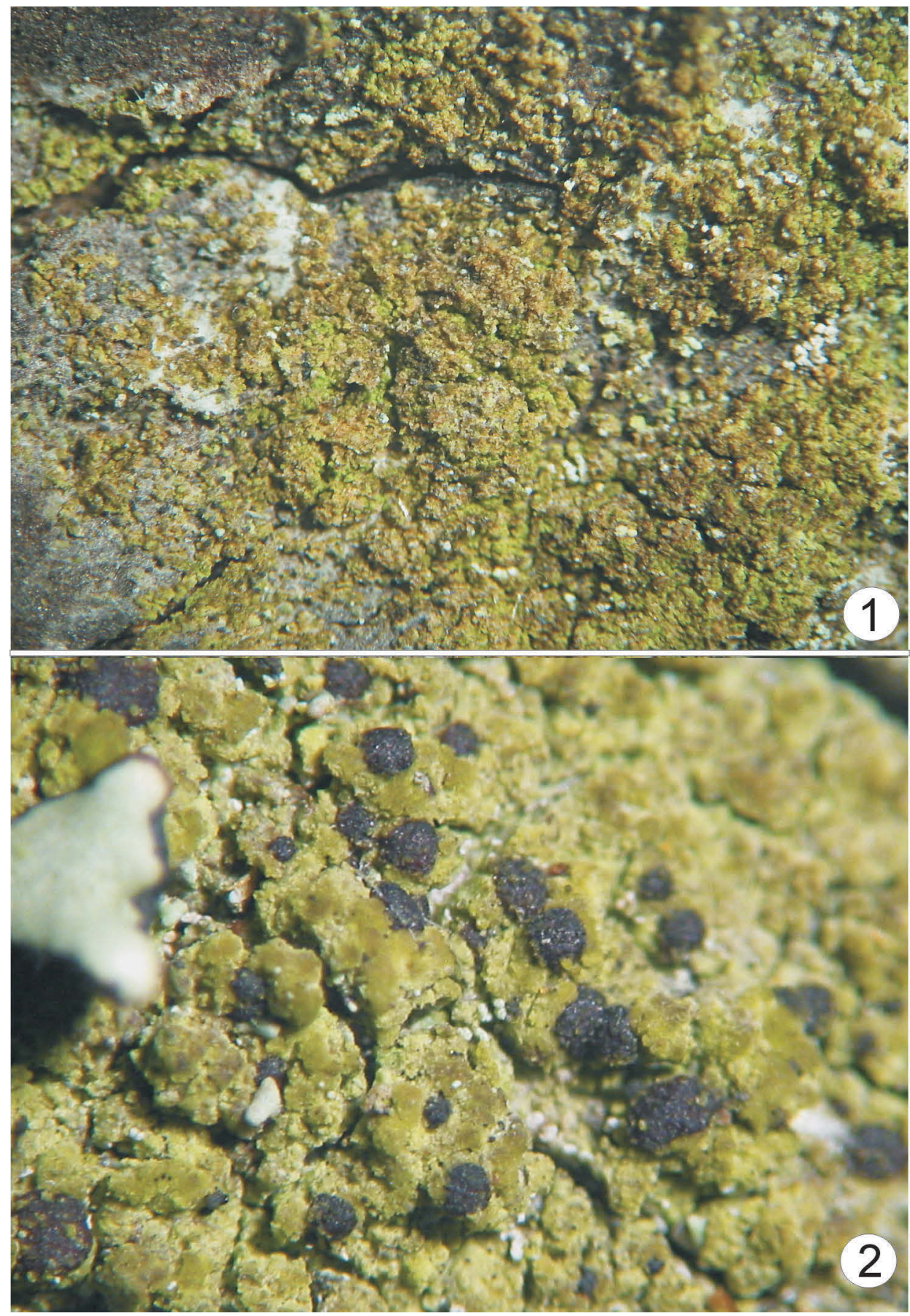

Figs 1-2. Habits of Japewia: 1. J. subaurifera (Czarnota, GPN 5981), 2. J. tornoensis (Czarnota, GPN 5637). 

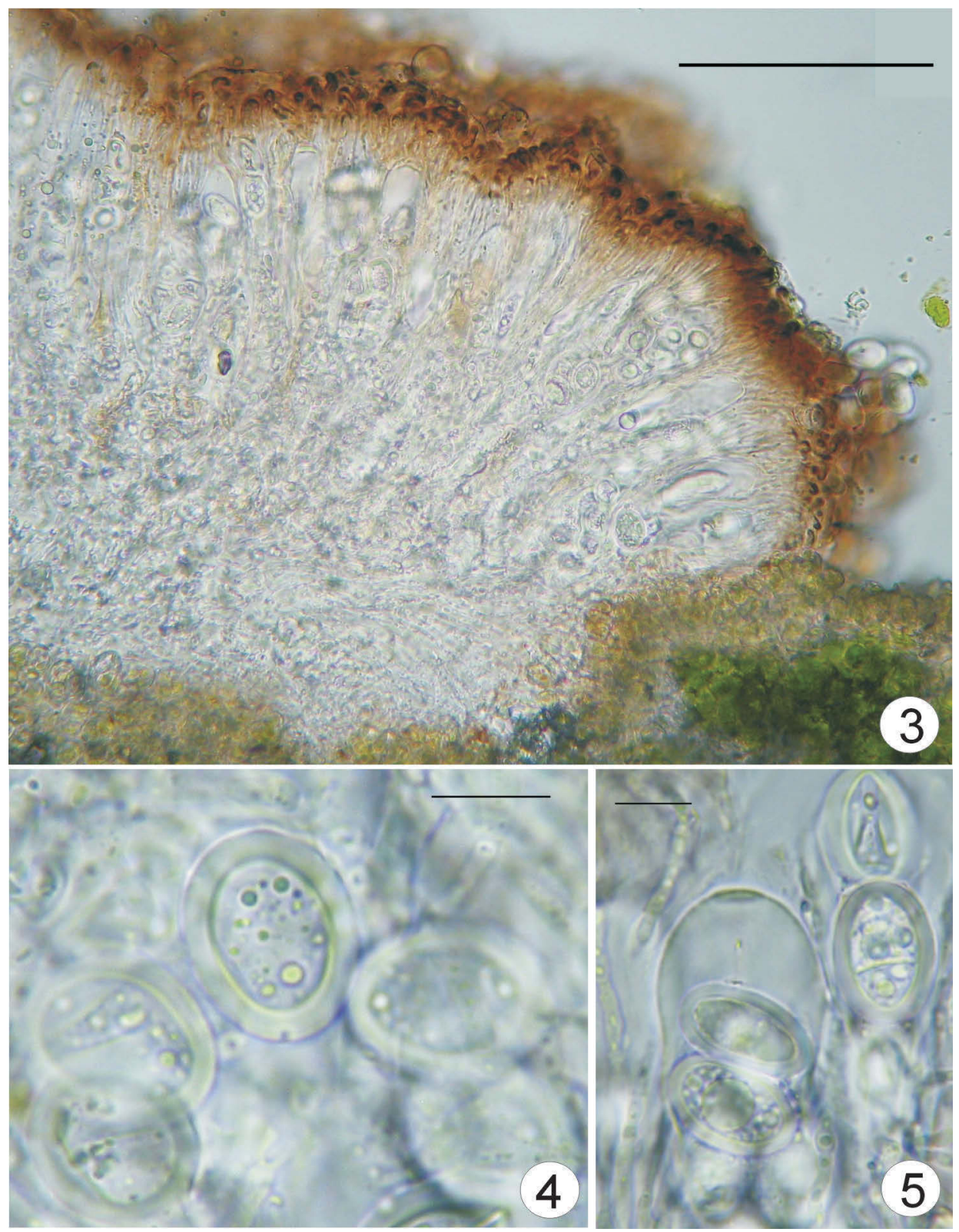

Figs 3-5. Japewia tornoensis (Czarnota, GPN 5637): 3. Apothecial section. Scale bar $=100 \mu \mathrm{m}$, 4-5. Ascospores with strongly thickened walls. Scale bars $=10 \mu \mathrm{m}$. 